\title{
THE MEASUREMENT AND MEANING OF PYURIA
}

BY

\author{
J. M. STANSFELD \\ From Dryburn Hospital, Durham
}

(RECEIVED FOR PUBLICATION NOVEMBER 3, 1961)

It seems strange that while the number of cells in blood or cerebrospinal fluid is counted as accurately as possible, we are content with crude estimations for the cells in urine. Thus the usual method of measuring pyuria is to look at a drop of urine under a microscope and see how many cells there are within a field viewed by high power magnification (1/6). No attempt is made to measure the volume of urine examined, but it will be small, perhaps $1 / 500 \mathrm{c} . \mathrm{mm}$. and will vary according to the size of the drop held by the coverslip. The amount will be adequate if large numbers of cells are present, but when there are relatively few, as there may be in chronic pyelonephritis, then it is too small to be reliable. In order to overcome this, many prefer to concentrate the urine first by centrifuging. But further difficulties are then raised, for each examination will take at least 10 minutes and probably require to be done in a laboratory, since few will be persuaded to use a centrifuge in the ward sideroom or in the surgery. Moreover, there are still inaccuracies. The volume of urine, the time and the rate of centrifugation may all be fixed, but in the end the final aliquot is unmeasured and reliance is still placed on a crude high-power field (henceforth referred to as H.P.F.) count.

\section{Methods of Measuring Pyuria}

The Counting Chamber Method. For some years I have routinely used a counting chamber for estimating the number of cells in the urine. The procedure is simple. The unspun urine is well mixed and a drop put into a Neubauer counting chamber. After allowing time for the cells to settle, a count is made of the number in two large squares, and the result multiplied by five will give the c.mm. count. This method seems preferable to others, for it enables small amounts of pyuria to be detected and comparison to be made between one specimen and another. No claim is made that the technique is original, for it was described by Block and Nyun in 1916, and has been advocated by Dukes (1928), Ockerblad (1928), Masters (1953) and others.
Correlation with Other Methods. In a previous paper (Stansfeld and Webb, 1953) counts per c.mm. were compared with those per H.P.F. This proved difficult as H.P.F. counts might vary by over $100 \%$, according to the size of the drop put on the microscope slide, but even so an average of one cell per H.P.F. was found to be approximately equivalent to some $250-500$ cells per c.mm.

Such observations were made on urines as voided, but since in many laboratories centrifuged deposits are used, it is also desirable to know how cubic millimetre counts on unspun urine compare with those per H.P.F. after centrifuging. Accordingly, suitable urines were selected and on each a c.mm. count was made, then $5 \mathrm{ml}$. was centrifuged at 4,000 r.p.m. for 10 minutes, after which the supernatant fluid was drained off, the deposit resuspended in the last drop or two and examined under a coverslip, an average H.P.F. count being made from at least 20 separate fields. Again the findings were scattered, but from 20 paired counts spaced over a range of three to 1,150 cells per c.mm. it was found that one cell per H.P.F. in the deposit was equivalent to five or six per c.mm. in the unspun urine. The inaccuracies of the final H.P.F. count could largely be eliminated by resuspending the deposit in $1 \mathrm{ml}$. of the original uncentrifuged urine and then using a counting chamber. This was done for 20 urines selected over the same range of c.mm. counts. The results were more consistent and whilst theoretically the resuspended deposit is a sixfold concentration of the parent urine, in fact an average of 5.6 was obtained.

Microscope field counts are variable and this was evident when the reliability of the various methods of estimating pyuria was tested by doing repeated counts on the same specimen of urine. Urines were selected with a reasonable but not too high cell content, for it was found difficult to count more than 20 cells in a H.P.F. The coefficients of variation are given in Table 1, being smaller for methods using a counting chamber than those involving H.P.F. estimations. 
TABLE 1

RELIABILITY OF FOUR METHODS OF COUNTING CELLS IN URINE

\begin{tabular}{|c|c|c|}
\hline Method & $\begin{array}{l}\text { Number of } \\
\text { Observations }\end{array}$ & $\begin{array}{l}\text { Coefficient of } \\
\text { Variation }(\%)\end{array}$ \\
\hline $\begin{array}{l}\text { Uncentrifuged Urine } \\
\text { Counting chamber method } \\
\text { High-power microscope field } \\
\text { counts } \\
\text {. . }\end{array}$ & $\begin{array}{l}43 \\
15\end{array}$ & $\begin{array}{r}8 \cdot 8 \\
50 \cdot 0\end{array}$ \\
\hline $\begin{array}{l}\text { Centrifuged Urine } \\
\text { Counting chamber method } \\
\text { (deposit resuspended in } 1 \mathrm{ml} \text {. } \\
\text { original urine) } \\
\text { High-power microscope field } \\
\text { counts (deposit resuspended } \\
\text { in last few drops) } \ldots\end{array}$ & 12 & $10 \cdot 4$ \\
\hline
\end{tabular}

Survival of Cells in Urine. It seems pertinent to know how long leucocytes persist in urine and whether, as some believe (Kleeman, Hewitt and Guze, 1960), specimens always need to be tested fresh. In fact cell survival was found largely to depend on the reaction of the urine. In an acid urine, below $p \mathrm{H} 6 \cdot 8$, cells survive remarkably well, and no significant reduction was found in repeated counts over 48 hours and sometimes up to 72 hours. But as the urine becomes increasingly alkaline, over $p \mathrm{H} 6 \cdot 8$, cells become more and more rapidly destroyed until at $p \mathrm{H} 8.4$ the majority disappear within a few minutes. The figure gives a graph of serial cell counts on four urine specimens which were adjusted to various $p \mathrm{H}$ values.

Two practical conclusions seem to follow from these observations. First, although examination of fresh urine is desirable, there can be a delay of up to 48 hours without significant alteration in cell count providing that the specimen remains acid. Thus, should a child be unable to produce a sample

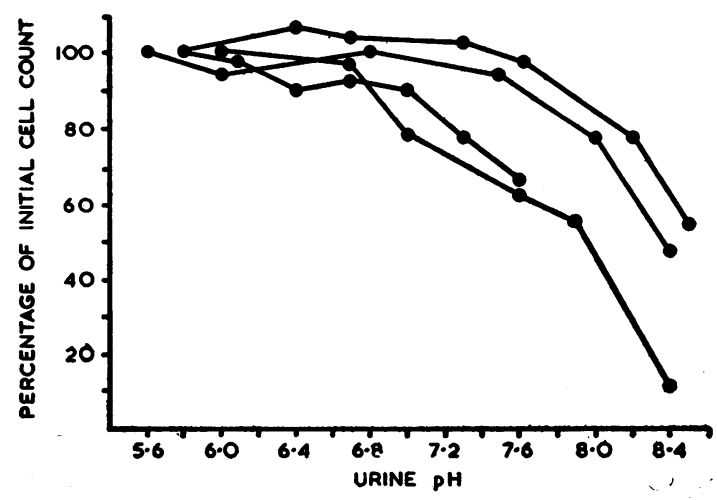

FIG. 1.-Serial cell counts on four urines adjusted to various $p H$ values.
TABLE 2

AGE AND SEX OF CHILDREN IN HOSPITAL WHO HAD URINE CELL COUNTS

\begin{tabular}{c|c|c|c}
\hline Age & Male & Female & Total \\
\hline- 1 month & 73 & 70 & 143 \\
- 1 year & 271 & 191 & 462 \\
- 5 years & 356 & 231 & 587 \\
-14 years & 424 & 384 & 808 \\
\hline Total & 1,124 & 876 & 2,000 \\
\hline
\end{tabular}

when seen, the mother can later obtain one and send it by post. Secondly, if the urine is strongly alkaline, the absence of pyuria does not necessarily rule out a urinary tract infection for, as has been encountered in Proteus infections, the cells may be destroyed and only debris remain.

\section{Incidence of Pyuria Found on Routine Examination of Urines from Children in Hospital}

To determine how frequently pyuria occurs routine counts using the counting chamber method were made on urines from children admitted to a general paediatric unit. In order to avoid any selection it was intended that a specimen should be obtained from every child, but regrettably 37 were missed in 2,037 consecutive admissions. In 16 of these the urine collection was forgotten, and in the rest there was insufficient time to obtain a specimen, either because of the child's quick death or owing to rapid transfer to another hospital for special treatment. There was no reason to suspect a kidney lesion in any of those whose urine was not tested.

It is felt, then, that the sample, although selected in that it is made up of children requiring hospital admission, is nevertheless representative of this group, $82 \%$ of whom were emergencies. The age and sex distribution are given in Table 2.

As an occasional cell in the urine might easily be overlooked, the analysis was confined to those having 10 or more in a cubic millimetre of an uncentrifuged well-shaken sample. Cells to this extent were found in the urines of 314 of the 2,000 cases examined. In 39 they were predominantly red cells, and in the remaining 275 they were mostly or solely polymorphonuclear leucocytes. In at least 67 further cases (often newborn infants) epithelial cells were seen, but counts were seldom made and their presence may not always have been recorded.

The figures above are the results of the examination of a single urine specimen from each case. Whenever the diagnosis was obscure or there was reason to suspect a kidney lesion repeated samples were 
TABLE 3

AGE AND SEX OF CASES HAVING PYURIA (10 or more cells/c.mm.)

\begin{tabular}{c|c|c|c}
\hline Age & Male & Female & Total \\
\hline - 1 month & $4(5 \cdot 5)$ & $14(20 \cdot 0)$ & 18 \\
- 1 year & $22(8 \cdot 1)$ & $45(23 \cdot 6)$ & 67 \\
-5 years & $19(5 \cdot 3)$ & $53(22 \cdot 9)$ & 72 \\
-14 years & $8(1 \cdot 9)$ & $120(31 \cdot 2)$ & 128 \\
\hline Totals & $53(4 \cdot 7)$ & $232(26 \cdot 6)$ & 285 \\
\hline
\end{tabular}

Figures in parenthesis indicate $\%$ admissions.

examined. In this way a further 10 children without cells in their original samples were subsequently shown to have developed pyuria. Thus 'pyuria', taking this to mean a concentration of polymorphonuclear leucocytes amounting to 10 or more cells in a cubic millimetre of fresh uncentrifuged urine, was demonstrated in $285(14 \%)$ of the children whose urines were tested. The incidence might well have been higher had repeated samples been examined from all and not just a few cases.

Table 3 gives the age and sex of the cases in which pyuria was found. Girls predominate and this seems particularly significant as there were fewer girls than boys admitted. The sex difference holds for all age groups, but it is most marked in children of school age. Furthermore, it seems that not only is pyuria less frequent in boys, but when it does occur it tends to be in smaller amounts (Table 4).

\section{The Meaning of Pyuria}

What is Significant. Since pyuria is a relatively frequent finding amongst children in hospital, the question arises as to what it means and how much importance should be attached to it. In each case the fundamental distinction between normal and abnormal must first be made, but this is not easy as there is no generally accepted definition of what constitutes 'significant' pyuria. Opinions differ concerning the maximum limit of normal excretion. Many would consider one or two cells per H.P.F. in uncentrifuged urine as within normal limits. Campbell (1951) even accepts up to one per lowpower field. In recent years pyuria has been defined by Straffon and Engel (1960) as over three cells, by Kass (1956) and by Riley and Knight (1958) as five or more cells, and by Michie (1959) as over 20 cells, all per H.P.F. on centrifuged deposits, although it is not always stated what volume of urine is involved.

Possibly the different estimates of normal leucocyte excretion in urine are not so much due to inadequate counting methods as to the fact that there is often no distinction made between urines
TABLE 4

DEGREE OF PYURIA (FIRST SPECIMEN TESTED)

\begin{tabular}{c|c|c|c}
\hline Amount (cells/c.mm.) & Male & Female & Total \\
\cline { 2 - 3 } & 25 & 45 & 70 \\
\hline $10-$ & 12 & 73 & 85 \\
$50-$ & 3 & 28 & 31 \\
$100-$ & 9 & 49 & 58 \\
$500-$ & 1 & 13 & 14 \\
1,000 and over & 2 & 15 & 17 \\
\hline
\end{tabular}

that are naturally voided and those caught midstream after cleansing or obtained by catheter.

The way the specimen is obtained is especially important in females whose urine is so frequently 'contaminated' by cells being introduced from the vulva during micturition. Such contamination may be considerable, the cell counts being comparable to those found in established urinary tract infections and on occasions amounting to over 1,000 per c.mm. It thus appears unlikely that for ordinary urine specimens from females there will be any critical level of cell count separating significant pyuria from that due to contamination. On the other hand, if after thorough cleansing of the vulva the urine is caught midstream or obtained by catheter the cell content will be small and limited, no greater than that of male urines which are seldom contaminated. Masters (1953), Stansfeld and Webb (1953) and Rupp (1959) independently found that urines obtained by catheter in either sex or naturally voided in boys contained less than 10 cells per c.mm. in over $92 \%$ of normal children. Probably the findings are the same for adults since Rofe (1955), Houghton and Pears (1957) and Hutt, Chalmers, MacDonald and de Wardener (1961), making observations on specimens obtained naturally from men but avoiding contamination from the foreskin, or by catheter from women, found maximal limits of excretion of between 131,000 and 400,000 leucocytes per hour, which at a daily urine output of $1,500 \mathrm{ml}$. would amount to two to six cells per c.mm.

Significant pyuria may thus be defined as 10 or more leucocytes per c.mm. in an unspun sample of clean or catheter urine.

Correlation with Bacterial Counts. If it is confirmed that significant pyuria is present the next step is to see if the urine is infected. Simple culture is not sufficient for this purpose since organisms as well as cells may enter the urine through contamination and even the few that may get into a clean specimen will quickly multiply. This rapid growth of bacteria in urine allows bacilluria due to con- 
TABLE 5

RELATION OF CELL TO BACTERIAL COUNTS IN 250 CLEAN MIDSTREAM SPECIMENS OF URINE FROM CHILDREN HAVING PYURIA IN THEIR ORDINARY SPECIMENS

\begin{tabular}{c|c|c|c}
\hline \multirow{2}{*}{$\begin{array}{c}\text { Cell Counts } \\
\text { per c.mm. }\end{array}$} & \multicolumn{3}{|c}{ Bacterial Counts $/ \mathrm{ml}}$. \\
\cline { 2 - 3 } & $\begin{array}{c}\text { Sterile or } \\
<10,000\end{array}$ & $\begin{array}{c}10,000- \\
100,000\end{array}$ & $>100,000$ \\
\hline$<10$ & 101 & 7 & 3 \\
$10-100$ & 39 & 13 & 10 \\
$>100$ & 18 & 15 & 44 \\
\hline
\end{tabular}

tamination and that resulting from urinary tract infection to be distinguished by means of bacterial counts. Infected urine which has been retained in the bladder will be likely to contain large numbers of organisms, whereas urine that has been contaminated during voiding will, if tested quickly and before the bacteria have time to multiply greatly, contain relatively few.

As in the elucidation of pyuria clean midstream urines, preferably first morning samples, are satisfactory in either sex, and providing that examination is carried out within an hour a count of under 10,000 organisms per ml. is likely to be due to contamination, whilst an excess of 100,000 per ml. indicates that urinary tract infection is present.

A clean midstream sample is thus required in order to elucidate pyuria and bacilluria alike and in practice the same specimen can be used for both cell and organism counts. But in order to interpret the findings it is necessary to know how bacterial counts correlate with cell counts. Various authors have made observations on this. Kass (1956), arbitrarily defining pyuria as five or more white cells in a high power microscope field of centrifuged urine, found it to be present in a third to a half of his patients with true bacilluria but only in $2 \%$ of those with bacterial counts less than 100,000 per ml. He concludes that "pyuria is of value diagnostically only when it is clearly present. Its absence from any single specimen cannot be taken as evidence of absence of bacilluria'. Sanford, Favour, Mao and Harrison (1956) could not demonstrate leucocytes in 13 of 91 specimens containing over 10,000 bacteria per $\mathrm{ml}$. They state that the absence of pyuria in single or multiple urine specimens does not negate the diagnosis of urinary tract infection, neither does the presence of pyuria imply that it is present.

Riley and Knight (1958), in a study of urinary infections in 44 patients with paralytic poliomyelitis, also correlated bacterial counts with pyuria. Their definition of pyuria was the same as that used by Kass, and they found it to be present in $54 \%$ of specimens with bacterial counts over 100,000 per $\mathrm{ml}$. and $21 \%$ of those with smaller counts. They made the point that pyuria is frequently absent in heavy bacilluria when infections are due to Proteus.

A criticism of all this work is that the estimations of pyuria are too haphazard. Bacterial counts are made precisely but the cell counts are approximations. If significant pyuria is taken as 10 or more cells per c.mm. in uncentrifuged clean or catheter urine then the correlation between pyuria and bacilluria might be closer. In order to see if this is so, whenever routine examination of urine from children in hospital has disclosed 10 or more white cells per c.mm., a midstream or occasionally catheter sample has been obtained for bacterial and cell counts. In this way, during the past two years, 250 specimens have been tested from 129 children. The findings are given in Table 5. Bacterial counts, made by the method described by O'Sullivan, FitzGerald, Meynell and Malins (1960), have been put into three groups: sterile or less than 10,000 organisms per ml. (which are probably contaminants), over 100,000 per ml. indicating urinary tract infection and a doubtful group between the two. The cell counts have also been put into roughly equivalent groups.

There was a fairly close correspondence between bacilluria and pyuria, $145(58 \%)$ of the urines containing either very few cells and organisms or considerable numbers of both. Moreover, and this seems particularly important, it was unusual to have a significant bacterial count without corresponding pyuria, only three examples being encountered. In one the bacteria appeared to be contaminants and there may have been a delay before testing, permitting multiplication, for there were large numbers of mixed organisms that were not present in subsequent specimens. The two other examples of heavy bacilluria without significant pyuria are unexplained for they were urines from children with Esch. coli urinary tract infections, and in each case further specimens contained large numbers of cells as well as organisms.

In general the absence of significant pyuria, with only few exceptions, makes it unlikely that the urine is infected. Pyuria, on the other hand, not infrequently occurs without bacilluria. For this there seem to be several possible reasons. Inadequate cleansing may leave a few cells as contaminants or, as Hepler and Scott (1935) found, pyuria may occur with infections outside the urinary tract. Then there may be urinary tract infection (as in 11 of the 18 with cell counts greater than 100 per c.mm. and only small numbers of bacteria), but bacterial growth is inhibited by antibiotics or not given time owing to quick transit through the bladder.

In Table 6 are shown various possible combina- 
TABLE 6

POSSIBLE COMBINATIONS OF PYURIA AND BACILLURIA WITH SUGGESTED INTERPRETATIONS

\begin{tabular}{|c|c|c|}
\hline \multicolumn{2}{|c|}{$\begin{array}{l}\text { Clean Midstream or } \\
\text { Catheter Urine }\end{array}$} & \multirow{2}{*}{ Suggested Interpretations } \\
\hline $\begin{array}{c}\text { Pyuria } \\
(>10 \text { cells } \\
\text { per c.mm. })\end{array}$ & $\begin{array}{c}\text { Bacilluria } \\
(>100,000 \\
\text { organisms } \\
\text { per ml. })\end{array}$ & \\
\hline $\begin{array}{l}+ \\
\text { o } \\
+\end{array}$ & $\begin{array}{l}+ \\
\text { o } \\
\text { o }\end{array}$ & $\begin{array}{l}\text { Urinary tract infection } \\
\text { No infection demonstrated } \\
\text { Urinary tract infection but bacterial } \\
\text { growth inhibited by antibiotics or } \\
\text { limited because of short time in blad- } \\
\text { der; oR } \\
\text { no urinary tract infection, cells from } \\
\text { contamination (cleansing inadequate), } \\
\text { due to extra-urinary tract infection or } \\
\text { non-infective renal disease } \\
\text { Urinary tract infection, cells destroyed } \\
\text { by alkaline urine; OR } \\
\text { no urinary tract infection but bacterial } \\
\text { contamination and growth before } \\
\text { examination }\end{array}$ \\
\hline
\end{tabular}

tions of bacilluria and pyuria with suggested interpretations. Cells may be destroyed in a strongly alkaline urine and bacteria fail to multiply through lack of time or because they are inhibited by antibiotics. Inadequate cleansing can result in cell contamination, and standing for two hours at room temperature before testing will permit bacterial multiplication after voiding (Kass, 1956).

Classification of Pyuria. By means of cell and bacterial counts pyuria may be classified into three types:

Contamination. Whatever the count in ordinary urine, and it is usually less than 1,000 cells per c.mm., a clean specimen will contain less than 10 cells per c.mm. providing that cleansing has been efficient. The culture will be sterile or the bacterial count less than 10,000 per $\mathrm{ml}$.

Urinary Tract Infection. A clean specimen contains 10 or more cells per c.mm. often in clumps or casts. Bacterial counts are over 100,000 per ml. unless inhibited by antibiotics or there has been quick transit through the bladder.

Unknown. Cells but not organisms are present in abnormal numbers in clean specimens. Followup fails to reveal any urinary tract infection.

TABLE 7

INCIDENCE OF DIFFERENT SORTS OF PYURIA AMONGST 2,000 CHILDREN IN HOSPITAL

\begin{tabular}{lll|c|c|c}
\hline & & & & Boys & Girls \\
\hline Contamination &. &. &.. & 47 & 178 \\
Urinary tract infection &.. &.. & 4 & 41 \\
Unknown.. &.. &.. &. & 2 & 13 \\
\hline
\end{tabular}

The frequencies of these different sorts of pyuria found amongst the 2,000 children in hospital are shown in Table 7. Contamination was the most common, being responsible for pyuria in $4 \%$ of the boys and $20 \%$ of the girls admitted.

Usually when pyuria is discovered it can readily be recognized as one of the types mentioned, but sometimes there are difficulties. The bacterial count, for instance, may be between 10,000 and 100,000 per ml., and so of doubtful significance. Then there may be both contamination and infection, each contributing to the cell content of the original urine so that the clean specimen count, although significant, will be much smaller and appear to be due to incomplete cleansing. Further specimens are needed to clarify such ambiguities.

Perhaps the greatest difficulty of all lies not in the interpretation of pyuria, but in its temporary absence in some cases of urinary tract infection, especially if this has been present for months or years. Cells and organisms may be present only intermittently, and negative findings do not rule out the presence of infection. Because of this, even using cubic millimetre cell counts, several specimens may sometimes be required in a suspected case or examinations postponed until symptoms suggest that the disease is more active again.

\section{Summary}

This paper is concerned with the detection and estimation of pyuria. The inadequacies of microscope field counts are mentioned and the measurement of pyuria using a counting chamber advocated.

Urine leucocyte counts by different methods have been compared. In uncentrifuged urine one cell per high-power field (H.P.F.) was found to be equivalent to 250 to 500 cells per c.mm. After centrifugation of $5 \mathrm{ml}$. urine an average of one cell per H.P.F. in the deposit corresponded to five to six cells per c.mm. uncentrifuged. The deposit from $5 \mathrm{ml}$. of urine could be resuspended in $1 \mathrm{ml}$. of the original urine and then a c.mm. count would be sixfold concentration. Estimations involving microscope field counts were found to have higher coefficients of variation than those in which the counting chamber was used.

The survival of leucocytes in urine varies according to the reaction. In acid urine cells survived without significant reduction in count for 48 hours and sometimes longer. As the urine alkalinity increased over $p \mathrm{H} 6.8$ the cells were more rapidly destroyed. Counts in very alkaline urines are unreliable.

Urine cell counts have been made on 2,000 of 2,037 consecutive admissions to a general paediatric unit mainly dealing with emergencies; 285 , nearly 
$5 \%$ of the boys and $27 \%$ of the girls admitted, were found to have 10 or more white cells per c.mm. in their urine.

Owing to the frequent contamination of naturally voided urines, counts on clean midstream or catheter specimens are needed in order to judge the meaning of pyuria; 10 or more cells per c.mm. in such clean specimens are considered to be pathological.

Cell and bacterial counts made on 250 clean midstream or catheter urines from 129 children whose previous routine urine examinations had disclosed 10 or more cells per c.mm. have been compared. Of the specimens $58 \%$ contained either very few cells and organisms or considerable numbers of both. It was unusual for there to be significant bacilluria in the absence of pyuria, but moderate or even considerable pyuria might occur without bacilluria. Possible explanations for the various combinations of bacilluria and pyuria are suggested.

Pyuria due to contamination, urinary tract infection and unknown cause is distinguished, and the distribution amongst children in hospital is given. Difficulties of interpretation are faced but they do not outweigh the value of measurement.

I would particularly like to thank Professor S. D. M.
Court for reading the manuscript so patiently and making such helpful suggestions.

\section{REFERENCES}

Block, E. B. and Nyun, K. (1916). The importance of counting pus cells in the urine. Sth med.J. (Bgham, Ala.), 9, 972.

Campbell, M. F. (1951). Clinical Pediatric Urology. Saunders, Philadelphia.

Dukes, C. (1928). Some observations on pyuria. Proc. roy. Soc. Med., 21, 1179.

Hepler, A. B. and Scott, R. T (1935). The significance of pyuria in children. J. Amer. med. Ass., 105, 499.

Houghton, B. J. and Pears, M. A. (1957). Cell excretion in normal urine. Brit. med. J., 1, 622.

Hutt, M. S. R., Chalmers, J. A., MacDonald, J. S. and de Wardener, H. E. (1961). Pyelonephritis. Observations on the relation between various diagnostic procedures. Lancet, 1,351

Kass, E. H. (1956). Asymptomatic infections of the urinary tract. Trans. Ass. Amer. Phycns, 69, 56.

Kleeman, C. R., Hewitt, W. L. and Guze, L. B. (1960). Pyelonephritis. Medicine (Baltimore), 39, 3.

Masters, P. L. (1953). Urinary changes in infections of the urinary tract in childhood. Guy's Hosp. Rep., 102,76.

Michie, A. J. (1959). Pediatric urology-Summary of a round table. Pediatrics, 24, 1118.

Ockerblad, N. F. (1928). An accurate method of estimating pus and blood cells in urine. J. Urol. (Baltimore), 19, 525

O'Sullivan, D. J., FitzGerald, M. G., Meynell, M. J. and Malins, J. M. (1960). A simplified method for the quantitative bacterial culture of urine. J. clin. Path. 13, 527

Riley, H. D., Jr. and Knight, V. (1958). Urinary tract infection in paralytic poliomyelitis. Medicine (Baltimore), 37, 281.

Rofe, P. (1955). The cells of normal human urine. A quantitative and qualitative study using a new method of preparation. J. clin. Path., 8, 25.

Rupp, W. (1959). Uber die Leukocyten und Keimausscheidung im Urin gesunder Kinder bei Anwendung quantitativer Methoden. Ärztl. Wschr., 14, 132.

Sanford, J. P., Favour, C. B., Mao, F. H. and Harrison, J. H. (1956) Evaluation of the 'positive' urine culture; an approach to differentiation of significant bacteria from contaminants. Amer. J. Med., $20,88$.

Stansfeld, J. M. and Webb, J. K. G. (1953). Observations on pyuria in children. Arch. Dis. Childh. 28, 386.

Straffon, R. A. and Engel, W. J. (1960). Diagnosis and treatment of urinary tract infection in children. $J$ Amer. med. Ass., 174, 1377. 